\title{
Supply Chain Configuration Conundrum: How does the Pharmaceutical Industry Mitigate Disturbance Factors?
}

Fahian Huq, Kulwant S Pawar and Helen Rogers

\author{
Name: $\quad$ Dr Fahian Anisul Huq \\ Institution: Manchester Business School, \\ Address: $\quad$ Marketing, Operations Management and Service Systems Division \\ Room 3.67 MBS West, \\ Booth Street West, \\ Manchester M15 6PB, U.K. \\ E-mail: $\quad$ fahian.huq@mbs.ac.uk \\ Name: $\quad$ Professor Kulwant S Pawar \\ Institution: Centre for Concurrent Enterprise \\ Address: $\quad$ Nottingham University Business School, \\ University of Nottingham, \\ Jubilee Campus, \\ Nottingham, \\ NG8 1BB, U.K. \\ E-mail: $\quad$ Kul.Pawar@ nottingham.ac.uk \\ Name: $\quad$ Professor Helen Rogers \\ Institution: Technische Hochschule Nuernberg/University of Applied Sciences \\ Address: $\quad 90402$ Nuernberg, \\ Deutschland \\ E-mail: $\quad$ Helen.Rogers@th-nuernberg.de \\ Corresponding author: Professor Helen Rogers \\ [Corresponding Author's Email] Helen.Rogers@th-nuernberg.de
}




\title{
Supply Chain Configuration Conundrum: How does the Pharmaceutical Industry Mitigate Disturbance Factors?
}

Production Planning \& Control

http://dx.doi.org/10.1080/09537287.2016.1193911

\begin{abstract}
How a supply chain (SC) is configured can have a significant impact on the performance of global firms. More specifically, disturbance factors (i.e. those factors associated with uncertainty and risk) are increasingly important considerations. This paper focuses on endogenous, exogenous and environment-related SC disturbance factors and their relative importance when configuring global SCs. Three alternative scenarios of SC configurations for European-based pharmaceutical firms are identified - insource nearshore, outsource nearshore and outsource offshore. Through a multi-phase, mixed-method approach we find that the top five disturbance factors managers should be aware of while configuring their SCs are quality defects, unforeseen and random interruptions in manufacturing processes, order processing difficulties, untimely delivery of products, and a mismatch between market demand and supplier responsiveness. This study is able to provide insights into the impact of disturbance factors on the SC configuration strategy for Big Pharmas. We show that SC disturbances influenced the decision to bring production back home (reshoring) or to a closer location (near-shoring). To mitigate the effects of disturbances many Big Pharmas recalibrated their SC configurations by insourcing core products, outsourcing non-core products offshore and developing offshore insourcing capabilities through 'captives'.
\end{abstract}

Keywords: supply chains; pharmaceuticals, disturbance; risk, outsourcing, reshoring 


\section{Introduction}

Leading Western pharmaceutical manufacturers, the so-called Big Pharmas (BPs), have experienced high turnover from 'blockbuster' drugs, long patent lives and high returns on investments. However, this scenario is rapidly changing, as the billion-dollar 'blockbusters' are coming off patent and the BPs are struggling to develop new medicines to replace them (PWC, 2007; Skibo, 2013). Declining R\&D productivity and profits coupled with an increasingly competitive global market have led to seek ways to reduce production and material costs by outsourcing to cheaper locations, creating increasingly complex and more global supply chains (Peck, 2005; Zsidisin et al., 2005; Taps and Steger-Jensen, 2007). This in turn has caused BPs to focus on their core competencies such as $R \& D$ while outsourcing non-core functions to contract manufacturing organisations (CMOs) in low-cost emerging economies. This has been particularly evident in terms of the manufacture of generic drugs or those coming off patent (Enyinda et al., 2009; Marucheck et al., 2011). A further trend has been the sourcing of both active and inactive ingredients from developing (lower cost) countries. For example, AstraZeneca outsourced manufacturing of a key ingredient in one of its best-selling drugs to a CMO in China (Wall Street Journal, 2007). It also has dedicated sourcing centres in China (Shanghai) and India (Bangalore).

By implementing globally complex supply chains - where sourcing, manufacturing, packaging and distribution may occur at different locations - the potential for supply chain disturbances, i.e. risks and uncertainties, increases. This in turn can lead to lost market value, product recalls, regulatory actions, etc. (McKinsey, 2012) For example, in 2008 Baxter Healthcare was obliged to recall batches of heparin following 81 deaths associated with the product (Bloomberg, 2008). The US Food and Drug Administration (FDA)'s subsequent investigation led to the identification of ten suppliers of the Active Pharmaceutical Ingredient (API), the chemicals used to produce heparin, which had been manufactured in China and shipped to eleven countries (FDA, 2008). The quality and safety measures of the Chinese suppliers were found to be inadequate, placing the entire supply chain at risk (The Chartered Quality Institute, 2012). Johnson \& Johnson lost over $\$ 900$ million in revenue in 2010 owing to supply chain disturbances related to manufacturing and quality issues (New York Times, 2011). In 2009 its Tylenol product was recalled following consumer reports of gastrointestinal symptoms, believed to have been caused by a chemical used to treat wooden transportation pallets produced in the Dominican Republic (Rogers, 2010). These cases show that incidents can occur at all levels within the supply chain and any disturbances can potentially threaten patients' lives. Against this backdrop, the aim of this paper is to identify supply chain disturbance factors for pharmaceutical firms and to assist managers in deciding on the most appropriate supply chain configuration, given the level of disturbances in their supply chains. Three alternative SC configurations are investigated (a) insource nearshore, (b) outsource nearshore and (c) outsource offshore.

\section{Literature Review}

\subsection{Supply Chain Disturbances in the Pharmaceutical Industry}

Although many authors have sought to categorise risk and uncertainty in the supply chain context (Davis, 1993; Mason-Jones and Towill, 1998; Jüttner et al., 2003; Spekman and Davis, 2004; 
Jüttner, 2005; Peck, 2005; Rogers et al., 2012; Simangunsong et al., 2012), the two terms are still often used interchangeably (Pawar and Rogers, 2013). Despite the similarities, and even though both are forms of organisational disturbances, Rogers et al. (2012) preferred to distinguish between them by pointing out that risk has a probabilistic factor associated with it (Spekman and Davis, 2004) while uncertainty is a condition in which it becomes difficult to predict the likelihood of various future events (Srinivasan et al., 2011). Researchers have identified the following dimensions of risk and uncertainty - demand, supply, process, control, environment, location and national/business culture (Davis, 1993; Mason-Jones and Towill, 1998; Christopher and Lee, 2004; Jüttner, 2005; Wright and Albores, 2010).

Supply chain disturbances result in poorer performance on metrics such as inventory costs, efficiency of communication, lead time and responsiveness, as well as profitability and shareholder value (Hendricks and Singhal, 2005; Hendricks et al., 2009). Despite this the topic has so far received limited research attention (Bode et al., 2011; Simangunsong et al., 2012). Decisions on where to locate have primarily been based on cost measures, neglecting other factors such as internal and external supply chain-related disturbances (MacCarthy and Atthirawong, 2003; Tate et al., 2009). The trend towards outsourcing and in particular offshore manufacturing (Bhatnagar and Sohal, 2005; Peck, 2005; Zsidisin et al., 2005; Christopher and Holweg, 2011) has increased vulnerability to a range of disturbances such as hurricanes, earthquakes, political instability, etc. (Chopra and Sodhi, 2004, 2014; Craighead et al., 2007; Ellis et al., 2011) and economic factors such as wage inflation in lower cost countries (Simchi-Levi, 2010; Wagner and Neshat, 2012). Pharmaceutical MNC supply chain vulnerability to disturbances was exposed by the 2011 Japanese earthquake and tsunami that led to (among many other serious problems) interruptions in the supply of glycine, an ingredient for solid-dosage products and the gelatine used in soft gel capsules (Miller, 2011). It is challenging for companies with complex multi-tiered supply chains to manage all potential disturbances, and to date there has been limited research on this topic. Chen and Hung (2010) developed one of the first outsourcing manufacturing partner selection models for the pharmaceutical industry using an integrated fuzzy approach. Marucheck et al. (2011) identified safety challenges that arise in highly regulated industries, including problems of contamination, counterfeiting and secondary distributors in the pharmaceuticals industry. Gray et al. (2011) is the only paper identified that studied risk in the pharma supply chain using primary data. However, their focus was on the comparison of internal quality risk between onshore and offshore locations. Thus, a gap remains in terms of understanding the disturbances present in different supply chain configurations using empirical data and how they can be mitigated.

For this paper, by conducting an extensive literature review, sources of pharma-related supply chain disturbances were identified and grouped into endogenous (firm-related), exogenous (network-related) and environmental (location-related) disturbance factors. This is summarised in Table 1. Endogenous disturbance factors are related to the focal firm and include internal process (e.g. manufacturing processes, quality) and control (order processing, information flow) disturbances. Exogenous disturbance factors occur within the supply chain network, i.e. the focal firm and its partners, and comprise demand (e.g. mismatch between market demand and supplier responsiveness, difficulty in demand forecasting), supply (untimely delivery of products, mismatched inventory levels) and control (difficulty communicating with suppliers or transmitting 
data) disturbances. Environmental disturbances are related to the firm's choice of sites or manufacturing partners and include relative production costs; hidden costs of distant operations (e.g. increased lead times); geopolitical issues (man-made/natural disasters, societal disruptions, political instability); accessibility of logistics provision (road, sea and air freight services); reliability of energy (power), internal transport and telecommunication infrastructure; skills, education level and talent of the labour force; cultural differences; and Intellectual Property Rights (IPR) risks.

\begin{tabular}{|c|c|c|}
\hline $\begin{array}{l}\text { Endogenous } \\
\text { Factors }\end{array}$ & Description & Key Literature \\
\hline $\begin{array}{l}\text { Process } \\
\text { disturbance }\end{array}$ & $\begin{array}{l}\text { Unforeseen and/or random interruptions that } \\
\text { significantly affect operations e.g. machine } \\
\text { break downs, quality defects etc. }\end{array}$ & $\begin{array}{l}\text { (Davis, 1993; Mason-Jones and Towill, 1998; Geary, } \\
\text { 2002; Van Der Vorst and Beulens, 2002; Christopher } \\
\text { and Peck, 2004; Bhatnagar and Sohal, 2005; Sheffi and } \\
\text { Rice, 2005; Lockamy et al., 2008) }\end{array}$ \\
\hline $\begin{array}{l}\text { Control } \\
\text { disturbance }\end{array}$ & $\begin{array}{l}\text { Breaks in information flow that convert } \\
\text { customer orders into production targets and } \\
\text { supplier raw material requisition. }\end{array}$ & $\begin{array}{l}\text { (Mason-Jones and Towill, 1998; Wilding, 1998; Geary, } \\
\text { 2002; Christopher and Peck, 2004; Prater, 2005) }\end{array}$ \\
\hline \multicolumn{3}{|l|}{$\begin{array}{l}\text { Exogenous } \\
\text { Factors }\end{array}$} \\
\hline $\begin{array}{l}\text { Demand } \\
\text { disturbance }\end{array}$ & $\begin{array}{l}\text { Difference between the actual end } \\
\text { marketplace demand and orders placed } \\
\text { within an organisation by customers e.g. the } \\
\text { 'bullwhip effect'. }\end{array}$ & $\begin{array}{l}\text { (Davis, 1993; Fisher, 1997; Mason-Jones and Towill, } \\
\text { 1998; Prater } \text { et al., 2001; Van Der Vorst and Beulens, } \\
\text { 2002; Christopher and Peck, 2004; Prater, 2005; } \\
\text { Lockamy et al., 2008) }\end{array}$ \\
\hline $\begin{array}{l}\text { Supply } \\
\text { disturbance }\end{array}$ & $\begin{array}{l}\text { Disruptions e.g. due to quality, } \\
\text { environmental, health or safety issues } \\
\text { leading to untimely delivery of products or } \\
\text { mismatched inventory levels. }\end{array}$ & $\begin{array}{l}\text { (Davis, 1993; Mason-Jones and Towill, 1998; Prater } \text { et } \\
\text { al., 2001; Geary, 2002; Lee, 2002; Van Der Vorst and } \\
\text { Beulens, 2002; Zsidisin, 2003a, b; Christopher and } \\
\text { Peck, 2004; Prater, 2005; Lockamy et al., 2008) }\end{array}$ \\
\hline $\begin{array}{l}\text { Control } \\
\text { disturbance }\end{array}$ & $\begin{array}{l}\text { Associated with the interruption of } \\
\text { information flow throughout the supply } \\
\text { network rather than only the firm itself. }\end{array}$ & $\begin{array}{l}\text { (Davis, 1993; Evans et al., 1993; Mason-Jones and } \\
\text { Towill, 1998; Wilding, 1998; Geary, 2002; Christopher } \\
\text { and Peck, 2004) }\end{array}$ \\
\hline \multicolumn{3}{|l|}{$\begin{array}{l}\text { Environmental } \\
\text { Factors }\end{array}$} \\
\hline $\begin{array}{l}\text { Relative } \\
\text { production } \\
\text { costs per region }\end{array}$ & $\begin{array}{l}\text { Comparative cost of labour, transport and } \\
\text { energy per region, productivity cost of } \\
\text { dispersed production systems. }\end{array}$ & $\begin{array}{l}\text { (Carter and Narasimhan, 1996; MacCarthy and } \\
\text { Atthirawong, 2003; Simchi-Levi, 2010; Porter and } \\
\text { Kramer, 2011) }\end{array}$ \\
\hline $\begin{array}{l}\text { Hidden costs of } \\
\text { distant } \\
\text { operations }\end{array}$ & $\begin{array}{l}\text { Increased physical distances increase } \\
\text { complexity and uncertainty leading to } \\
\text { hidden costs of distant operations. }\end{array}$ & $\begin{array}{l}\text { (Prater et al., 2001; Van Der Vorst and Beulens, 2002; } \\
\text { Simchi-Levi, 2010; Porter and Kramer, 2011) }\end{array}$ \\
\hline $\begin{array}{l}\text { Geopolitical } \\
\text { Issues }\end{array}$ & $\begin{array}{l}\text { Geopolitical factors can generally be } \\
\text { classified as governmental, natural and } \\
\text { societal disruptions. }\end{array}$ & $\begin{array}{l}\text { (Prater et al., 2001; Chopra and Sodhi, 2004; } \\
\text { Christopher and Peck, 2004; Bhatnagar and Sohal, } \\
\text { 2005; Hendricks and Singhal, 2005; Jüttner, 2005; } \\
\text { Peck, 2005; Chan et al., 2008; Knemeyer et al., 2009; } \\
\text { Ellis et al., 2011) }\end{array}$ \\
\hline $\begin{array}{l}\text { Accessibility of } \\
\text { logistics }\end{array}$ & $\begin{array}{l}\text { Availability and quality of land, sea and air } \\
\text { freight services. }\end{array}$ & $\begin{array}{l}\text { (Prater et al., 2001; Peck, 2005; Wu et al., 2007; } \\
\text { Simangunsong et al., 2012) }\end{array}$ \\
\hline
\end{tabular}




\begin{tabular}{|l|l|l|}
\hline Infrastructure & $\begin{array}{l}\text { Availability and reliability of land, power, } \\
\text { transport and telecoms infrastructure. }\end{array}$ & $\begin{array}{l}\text { (Prater } \text { et al., 2001; Bhatnagar and Sohal, 2005; Chan } \\
\text { et al., 2008; Simangunsong } \text { et al., 2012) }\end{array}$ \\
\hline $\begin{array}{l}\text { Labour force } \\
\text { quality }\end{array}$ & $\begin{array}{l}\text { Skill, education level, productivity and } \\
\text { availability of labour force. }\end{array}$ & $\begin{array}{l}\text { (MacCarthy and Atthirawong, 2003; Bhatnagar and } \\
\text { Sohal, 2005) }\end{array}$ \\
\hline Cultural factors & $\begin{array}{l}\text { Issues of trust, bureaucracy, corruption, } \\
\text { ethics, etc. leading to misunderstandings. }\end{array}$ & $\begin{array}{l}\text { (Wilding, 1998; Hofstede, 2001; Van Der Vorst and } \\
\text { Beulens, 2002; Rogers et al, 2015) }\end{array}$ \\
\hline $\begin{array}{l}\text { Intellectual } \\
\text { Property Rights } \\
\text { (IPR) }\end{array}$ & $\begin{array}{l}\text { Potential risk of infringement of IPR due to } \\
\text { outsourcing. }\end{array}$ & \begin{tabular}{l} 
(Cockburn et al., 2007; Pawar and Rogers, 2013) \\
\hline
\end{tabular}
\end{tabular}

Table 1: Disturbance Factors affecting Pharmaceutical Supply Chain 


\subsection{Mitigating Disturbances through Supply Chain Re-configuration}

Increasingly, large multinational firms, in an effort to simultaneously provide local responsiveness and global integration, are developing complex, differentiated supply chains which increases the likelihood of disturbances (Mizgier et al., 2015b). The complex and dynamic interactions between supply chain entities leads to considerable disturbances that can propagate up and down the supply chain - adversely affecting performance (Bhatnagar and Sohal, 2005; Blackhurst et al., 2007). Such disturbances can significantly reduce operational performance, profitability and shareholder value over the long term (Hendricks and Singhal, 2005; Hendricks et al., 2009). To counter such negative effects, various supply chain disturbance mitigation strategies have been examined in the research literature, mainly comprising of demand management (e.g. demand shaping), supply management (e.g. having strategic stock or a flexible supply base), product management (e.g. postponement), process improvements (e.g. quality control), supply chain integration (e.g. vendor managed inventory) and capital adequacy (e.g. through insurance cover) strategies (Tang, 2006; Mizgier et al., 2015a; Wiengarten et al., 2016). Even though at the macro level, supply chain configuration is one of the principal strategic supply decisions which can help multi-national firms mitigate the disturbances brought about by today's dynamic business environment, it has only received limited attention in previous research (Tang and Musa, 2011; Mizgier et al., 2012). That is why, it is important to understand how disturbances can be mitigated through supply chain re-configuration. What makes this more challenging is the fact that there is no 'one-size-fits-all' supply chain strategy and even the supply chain configuration of firms making similar products might differ due to some unique characteristics (Simchi-Levi, 2010).

As global markets are becoming increasingly competitive, firms are under immense pressure to reduce production and material costs, especially during difficult economic climate. In order to reduce costs firms have resorted to outsourcing their production to cheaper locations. Outsourcing can be off-shore i.e. the relocation of a firms manufacturing or other processes (distribution, business services, $R \& D$ etc.) to a foreign land to take advantage of less costly operations there or it can be nearshore i.e. the location is at a closer proximity to the country of origin than the off-shoring site e.g. Eastern European countries are near-shoring sites for Western European based firms, whereas India and China are off-shoring sites. However, the idea that location no longer matters and the cheaper the location the better, is increasingly being challenged due to a greater recognition of the total cost of highly dispersed supply chains and hidden costs of distance (Porter and Kramer, 2011). Thus, the inherent disturbances present in extended supply chains are causing firms to review their supply chain configuration (Mizgier et al., 2015b). As a consequence, some firms are actively considering reshoring and some, despite higher labour costs, have already started to bring a certain portion of production closer to home i.e. insource nearshore (Ellram et al., 2013). This ability to reconfigure key elements of the supply chain, as an alternative permutation from the current state can enable improvements in the supply of the product and help mitigate disturbances (Srai and Gregory, 2008). In this paper the relevant supply chain (re)configuration strategies available to large pharmaceutical firms to mitigate disturbance factors is identified. As most prior disturbance mitigation research does not take the characteristics of different industry specific supply chains into consideration (Wagner et al., 2014), this research aims to fill the knowledge gap concerning how BPs can reconfigure their supply chains to mitigate disturbances. 


\section{Methodology}

The key focus of this research is Big Pharmas (BPs) whose headquarters are in Europe but have a global presence in branded products and manufacturing sites in multiple countries. Big Pharma is defined here as those pharmaceutical firms with revenues in excess of $\$ 20$ billion. Currently nine firms in the world meet this criteria, and of those, five have their headquarters in Europe (Fiercepharma, 2013). Our study was longitudinal in nature, spanning five years (2010-15) and mainly focussed on two European-based BPs, which from now on are referred to as BP1 and BP2. Views from other BPs were incorporated via the participation of executives, e.g. Director Global Sourcing (BP3, Europe), VP (BP4, US) and the Head of R\&D (BP5, Europe), in three workshops.

\subsection{Research Design: Multi-phase, Mixed Methods Approach}

A multi-phase, mixed-methods approach was used to address the research objective of providing insights into the types of disturbances in the pharmaceutical supply chain and their mitigation strategies through supply chain reconfiguration (Onwuegbuzie and Collins, 2007; Bazeley, 2008). According to Saunders et al. (2009), the two key advantages of mixed methods are that it can be used for different purposes and it enables triangulation. Initially, relevant articles on supply chain disturbances (including supply chain risk, uncertainty and disruptions) were identified through searches of the Business Source Premier, ProQuest and Emerald databases. Analysis of selected papers led to the development of the preliminary list of disturbance factors. In the subsequent phases (Section 2.2), primary data was collected using mixed methods via workshops, semi-structured interviews, surveys, site visits in (UK/China/India); personal observations and firms' internal reports (see Figure 1). These multiple sources strengthened the analysis by allowing triangulation on important issues to cross-verify insights and findings. The intent of using such a multi-phase, mixed methods approach was to maximise the opportunity to observe relatively more completely the phenomenon, thereby gaining more robust insights. 


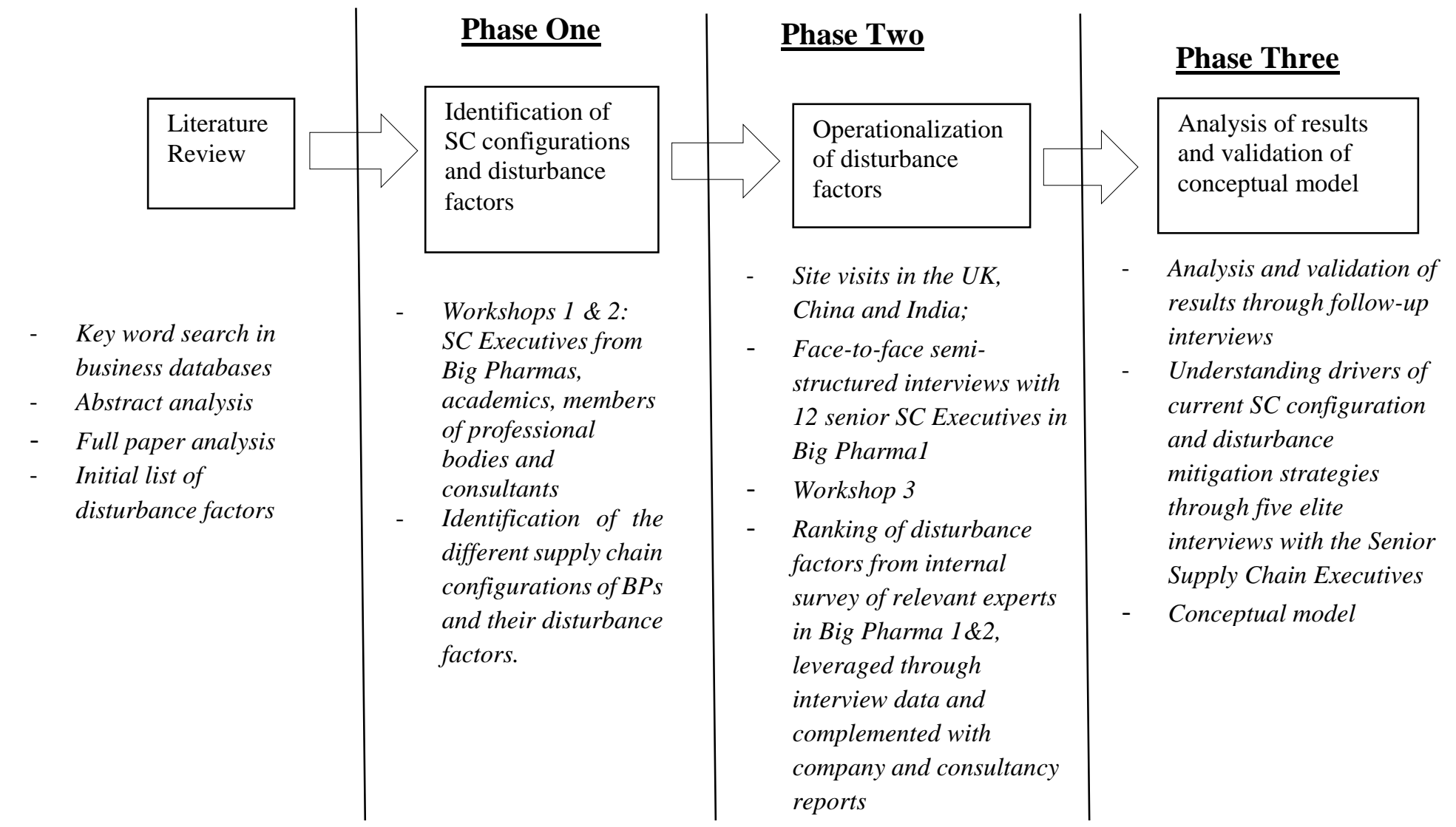

Figure 1: Research Design: Multi-stage, mixed-method approach 


\subsection{Data Collection and Analysis}

A three-phase empirical study involving different data sources and data collection methods was conducted. The supply chain is our unit of analysis as it is appropriate for the study of supply chain-wide disturbances and provides a more systematic and holistic understanding of the phenomena (Harland et al., 2003; Craighead et al., 2007). In Table 2, the timeline of the study, comprising year, location, data collection method and participant profile, is presented. Phase I entailed two highly participative and intensive three-hour focus group workshops held in India and China in 2011 with senior pharmaceutical executives - including participants from European and US-based BPs, academics, members of professional associations and industry consultants. Information was recorded by note taking, and afterwards a summary of the main points was circulated among the participants for validation. Through these workshops we were able to identify the different supply chain configurations of BPs and their disturbance factors.

\begin{tabular}{|c|c|c|c|}
\hline $\begin{array}{l}\text { Year \& } \\
\text { Location }\end{array}$ & $\begin{array}{l}\text { Data Collection } \\
\text { Method (of } \\
\text { interviews) }\end{array}$ & Participants/Interviewees (Designation) & \\
\hline 2011 India & $\begin{array}{l}\text { Focus Group } \\
\text { Workshop } 1\end{array}$ & $\begin{array}{l}12 \text { senior executives from the pharmaceutical industry - including } \\
\text { participants from the Europe based Big Pharma (BP) } 1 \& 2 \text {; } \\
\text { Director Global Sourcing of BP3 (Europe); VP of BP4 (US); } \\
\text { Senior Members of the Organisation of Pharmaceutical Producers } \\
\text { of India (OPPI) Global Sourcing Committee; Professors from } \\
\text { MIT, Indian Institute of Management \& Nottingham University. }\end{array}$ & : \\
\hline 2011 China & $\begin{array}{l}\text { Focus Group } \\
\text { Workshop } 2\end{array}$ & $\begin{array}{l}18 \text { senior executives from the pharmaceutical industry \& } \\
\text { academics e.g. Senior Manager Sourcing - BP1; Manager - } \\
\text { Supplier of BP1 \& academics from UK, USA \& the Chinese } \\
\text { European International Business School. }\end{array}$ & \\
\hline 2011-12 UK & Interview (x4) & Global Outsourcing Manager (BP1) & \multirow{8}{*}{ 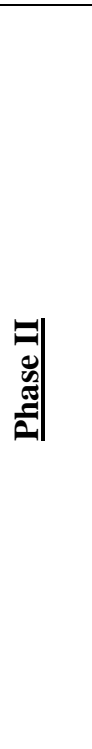 } \\
\hline 2011-12 UK & Interview (x2) & Supply Chain Director (BP1) & \\
\hline $\begin{array}{l}2011-12 \\
\text { China }\end{array}$ & Interview (x2) & Senior Manager Sourcing (BP1) & \\
\hline 2012 China & Interviews $(\mathrm{x} 4)$ & $\begin{array}{l}\text { Interviews with } 4 \text { senior executives of BP1 based in Shanghai } \\
\text { responsible for sourcing and managing suppliers. }\end{array}$ & \\
\hline 2012 India & Interviews (x3) & $\begin{array}{l}\text { Managing Director, Outsourcing Project Manager and Senior } \\
\text { Project Manager of BP1 based in India }\end{array}$ & \\
\hline 2012 UK & Interview (x2) & VP for Supply Chain (BP1, UK) and VP for R\&D (BP1, UK) & \\
\hline 2012 India & $\begin{array}{l}\text { Workshop } \\
\text { (approx.50 } \\
\text { attendees) }\end{array}$ & $\begin{array}{l}\text { Attendees consisted of high profile speakers, including managers } \\
\text { from BP1 \& BP5 (US) and Indian pharma suppliers/CMOs, } \\
\text { academics from UK \& India and government officials. }\end{array}$ & \\
\hline 2013 UK & Questionnaires & $\begin{array}{l}\text { Questionnaires were sent to } 11 \text { key SC executives based in the } \\
\text { European headquarters of BPs } 1 \& 2 \text {, responsible for the design, } \\
\text { planning and managing of the SC with an average of } 7 \text { years of } \\
\text { experience. }\end{array}$ & \\
\hline 2013-15 UK & Interviews in BP1 & $\begin{array}{l}\text { Senior Director, Supply Chain Management (x2) } \\
\text { Global Outsourcing Manager (x2) } \\
\text { Sourcing Director (x1) }\end{array}$ & 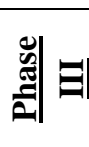 \\
\hline
\end{tabular}

Table 2: Timeline of the Study, Data Collection Methods and Participant Profile 
In Phase II (2011-13), we studied in detail the global supply chain of Europe-based BP1. By focusing on a single firm, in-depth information pertaining to the supply chain disturbance factors was obtained. In line with case study guidelines (Yin, 2009), we conducted site visits in the UK, China and India and also carried out seventeen face-to-face semistructured interviews with twelve senior executives, each lasting approximately an hour. Detailed notes were taken and then analysed along with the firm's internal reports, which enabled us to refine the final list of twenty disturbance factors. A third workshop was held in India where the challenges faced by BPs in a global context were discussed and debated. Participants included managers from BP1 and BP5, Indian pharma suppliers/CMOs, academics (UK and India) and government officials. Highlights focused around discussions on trends and developments in managing pharma supply chains at the regional, national and international level; comparative analysis of outsourcing destinations such as India and China and their implications for supply chain design; and finally comparisons of various supply chain configurations and their related disturbance factors.

We then went on to operationalise the disturbance factors in the different supply chain configurations by testing them in BP1 and BP2. As it is difficult to directly quantify "disturbance", a 5-point Likert scale was developed with the aim of assigning appropriate weights to the disturbance factors. The questionnaire comprised twenty questions relating to twenty disturbance factors, and respondents rated the level of disturbance in the three alternate supply chain scenarios. This was sent to eleven key supply chain European-based executives of BP1 and BP2, requesting that they rank the disturbance factors. Seven usable questionnaire responses were then analysed. The survey data was used to calculate weights for the individual disturbance factors, weights of disturbance factors across the different supply chain configurations and the total weight of disturbance in alternative supply chain configurations. The combined feedback consisting of the conceptual expertise of leading researchers and the experience of industry from the workshops, along with our interview data were leveraged to further support the ranking of disturbance factors. These were also complemented by relevant company and consultancy reports.

In Phase III (2012-15), five elite interviews were conducted with the Senior Supply Chain Director, Sourcing Director and Senior Outsourcing Manager dealing with suppliers in Europe, India and China of BP1. 'Elite' refers to managers with significant decision-making influence who can provide substantial meaning to a particular situation (Harvey, 2011). This revealed current trends in supply chain configuration strategies of BPs, their disturbance mitigation strategies and how possible future configuration models might look, given the disturbance factors. Furthermore, through these follow up interviews our ranking of disturbance factors was validated and it provided us with additional data to further strengthen the robustness of our weighting process. 


\section{Findings}

\subsection{Three supply chain configuration scenarios}

Phase I led us to identify the following three supply chain configurations (relevant for a large R\&D-based MNC headquartered in Europe but with a global presence and multiple locations across the world): insource nearshore, outsource nearshore, and outsource offshore. These were used as a basis for discussion with BP supply chain executives. As with all models, some simplifications and aggregations are made, resulting in depicting the model as a single, "generic" component (Davis, 1993). Accordingly, while building the various supply chain configuration models, the summarised characteristics of the aggregated parts were checked against expert opinion to ensure they adequately represent the situation. For example, as R\&D remains the pharmaceutical MNCs' core competency and their desire to retain control for sustained competitiveness, it has been assumed that the R\&D is carried out in Europe. It has also been assumed that in all three supply chain designs the raw materials are sourced from China. The markets considered outside Europe were Asia and Africa, owing to their high growth rates. North America was not considered as it is a mature market with low growth rate. In the following sections, the three different supply chain scenarios are presented in turn.

\subsubsection{Insource nearshore (Europe)}

Nearshore insourcing occurs when almost all activities take place in the country of origin (Europe) and there is no outsourcing (Erber and Sayed-Ahmed, 2005; Lalwani et al., 2007). As extended supply chains bring with them increased risks, focal firms need to evaluate their supply chain designs to make informed decisions regarding in-house or closer to home production options, i.e. insource. In this research, an MNC based in Western Europe is considered as the focal firm. Thus, in the first supply chain configuration, R\&D is carried out in Europe, raw materials are sourced from China and the manufacturing [Active Pharmaceutical Ingredient (API) and formulation] and subsequent packaging are carried out in Europe. From there it is transferred to a central distribution centre and transported to the customers (see Figure 2).

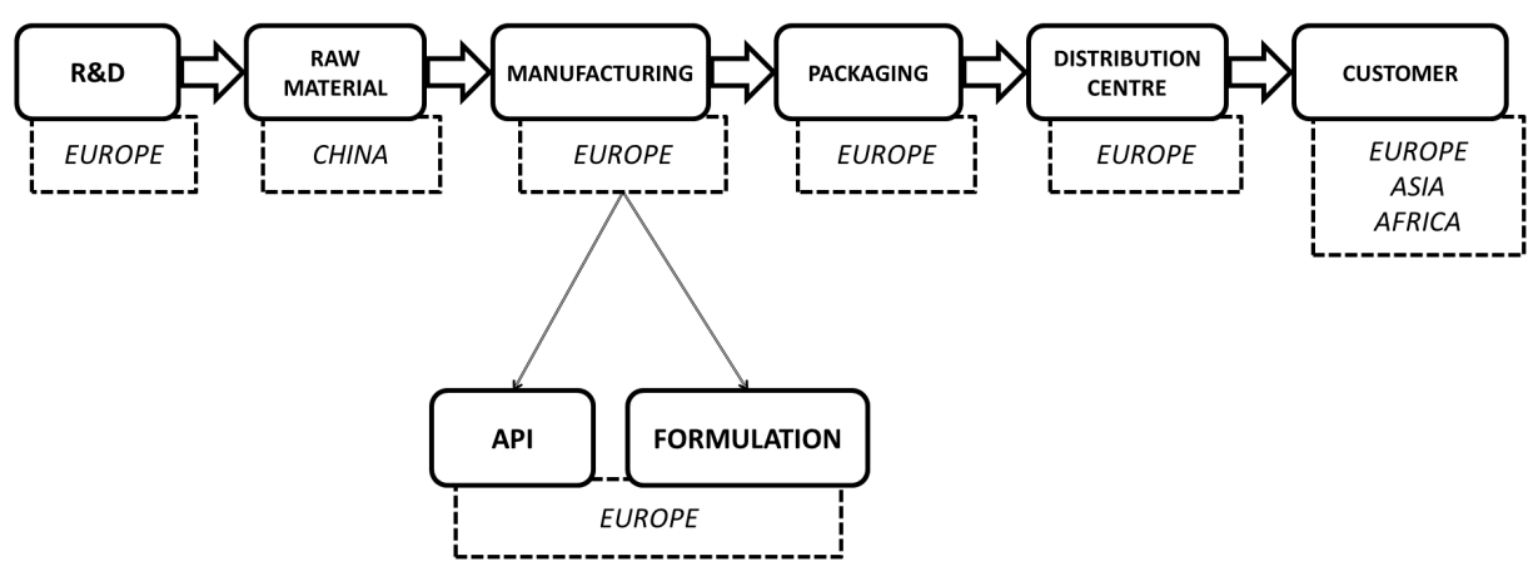

Figure 2: Insource Nearshore (Europe)

4.1.2 Outsource nearshore (Eastern Europe) 
Nearshore outsourcing implies that certain operations are outsourced to partner firms within Europe, and here we assume that one of the options for European MNCs is to locate to lowcost Eastern European countries. The United Nations Statistics Division (2013) defines Eastern European countries as Belarus, Bulgaria, Czech Republic, Poland, Russia, Slovakia, Ukraine, Romania, Hungary and Moldova. Pharmaceutical firms view manufacturing in Eastern Europe as attractive for several reasons; it has been identified as an emerging market by BPs such as Astra Zeneca (2010) and Pfizer (2010); it has highly educated and low-cost labour; and it has cultural similarities, a good knowledge of languages, solid technical skills and minimum regulatory problems for Western European firms (AT Kearney, 2005). While designing this supply chain configuration, $R \& D$ is considered to be taking place in Europe and the raw materials are sourced from China. The difference to the previous model is that all the manufacturing (API and formulation) is carried out in Eastern Europe, i.e. the supply chain strategy is nearshore outsourcing. Packaging takes place in a central European location to cater to the comparatively higher demand and stricter regulations of the larger advanced economies. From there it is transferred to distribution centre A (located in Europe), which serves customers in Europe and Africa, and distribution centre B (located in Asia), which serves customers in Asia (see Figure 3). Both distribution centres have the option to customise packaging according to the needs of the target location.

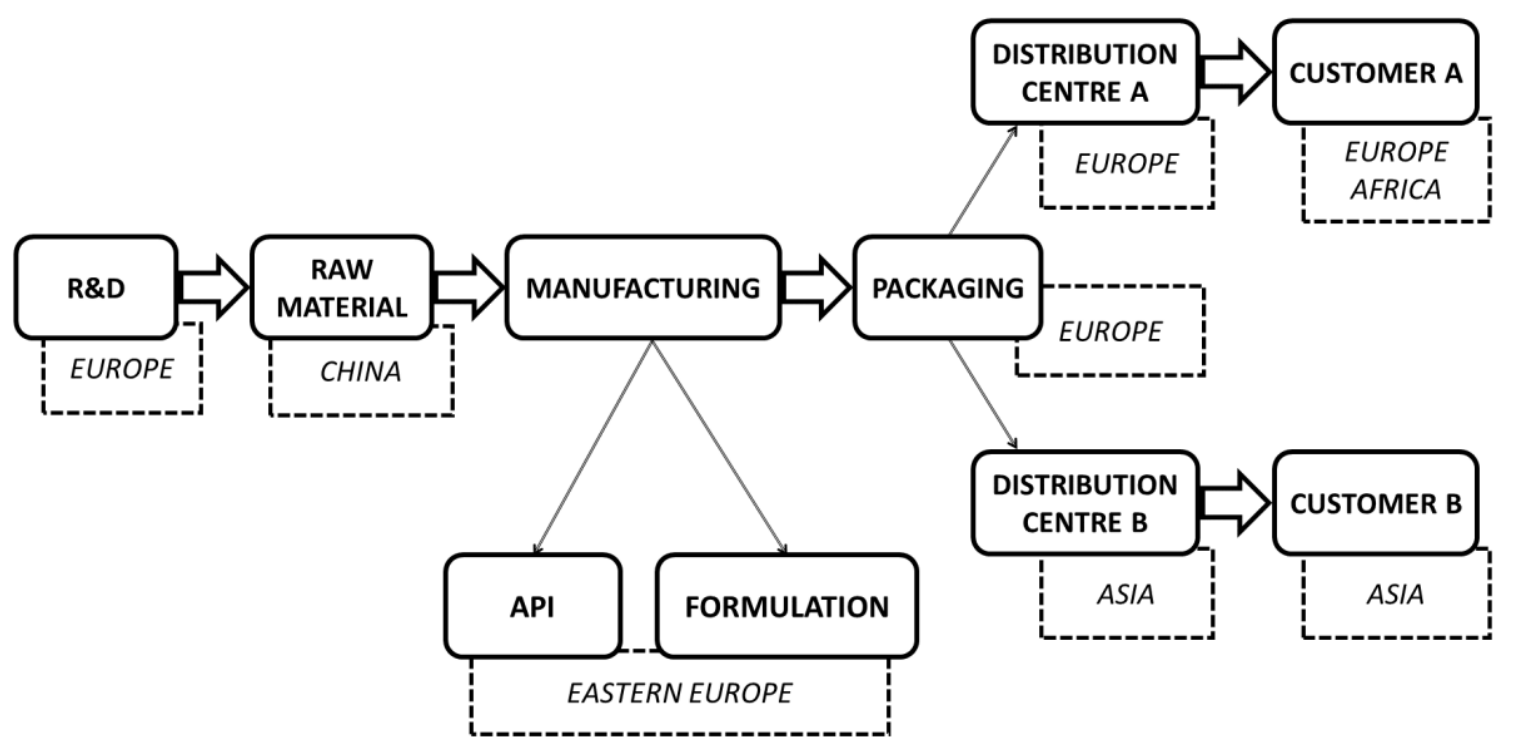

Figure 3: Outsource Nearshore (Eastern Europe)

\subsubsection{Outsource offshore (India/China)}

Offshore outsourcing occurs when parts of the value chain are transferred to firms outside the parent firm's national borders and the site is comparatively remote (Erber and Sayed-Ahmed, 2005; Lalwani et al., 2007). The third option is to outsource part of the manufacturing to Asia (specifically India/China). As Europe grapples with rising R\&D costs and declining drug outputs and as governments attempt to contain spiralling healthcare outlays, European pharmaceutical firms have been exploring emerging markets that offer a low-cost structure 
along with other potential benefits, such as sizeable domestic markets and opportunities for clinical-trial licensing (KPMG, 2011). Regulations also play a part e.g. in China it is quicker to register new drugs if some part of the development and/or manufacturing has taken place in China. This makes it strategically attractive to locate sourcing and manufacturing functions in Asia, as reflected in Figure 4, where the firms follow the strategy of offshore outsourcing to Asia. After packaging the goods in Asia, they are transported to two distribution centres; one in Europe (distribution centre A) catering to European and African markets and the other in Asia (distribution centre B), serving the Asian market.

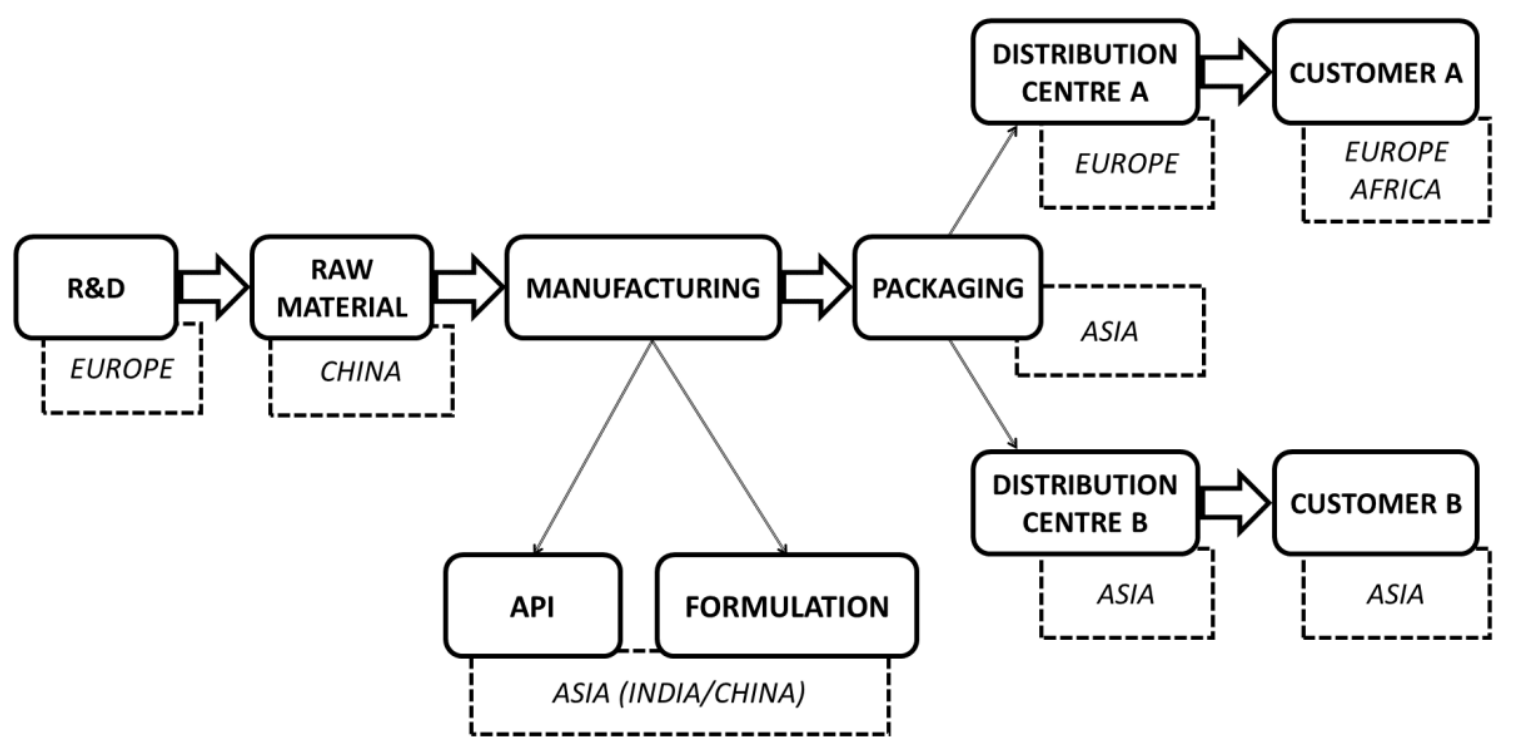

Figure 4: Outsource Offshore (India/China)

\section{Disturbance factors and mitigating strategies}

In this section we describe how the ranks have been arrived at, followed by specific issues pertaining to endogenous, exogenous and environmental disturbances. We then outline the mitigating strategies adopted by the pharmaceutical firms. The data from Phase II was used to calculate weights for the individual disturbance factors, weights of disturbance factors across the different supply chain configurations and the total weight of disturbance in alternative supply chain configurations, rather than provide statistically significant results. These rankings informed subsequent discussions with 'elite' interviewees in Phase III. By incorporating interviewees' perspectives, we were able to gain practical insights into different disturbance factors and explore the strategies deployed to mitigate them.

\subsection{Disturbance factor}

The calculated weight for each disturbance factor, representing its relative importance (and adding up to one), is shown in Table 3. This table reveals the top three most important disturbance factors are all related to internal process disturbances (endogenous) at the outsourcee/supplier firm, i.e. quality defects, unforeseen and random interruptions in 
manufacturing processes and difficulty in order processing. In contrast, the experts considered the disturbances created by reliability of energy (power), internal transport and telecommunication infrastructure; quality of skills, education level and talent of the labour force and natural disasters as least important - all three being environmental disturbance factors. This can be interpreted as follows: if a pharmaceutical sourcing professional has 100 minutes to devote to the list of disturbance factors, then he/she would spend approximately 6.34 minutes ensuring product quality (the highest ranked factor) and only 3.86 minutes on the issue of reliability of energy (power), internal transport and telecommunication infrastructure (the lowest ranked factor). This emphasises the relative importance of disturbances caused by quality defects, as compared to reliability of energy (power), internal transport and telecommunication infrastructure, or on a broader scale the importance of internal (endogenous) disturbances as compared to site/location (environmental) related disturbances. By ranking the weights, the most important disturbance factors can be identified, allowing additional time to be spent to improve these.

\begin{tabular}{|c|l|c|}
\hline Rank & Disturbance Factors & Weight (\%) \\
\hline 1 & Quality defects & 6.343 \\
\hline 2 & Unforeseen and random interruptions in manufacturing processes & 6.145 \\
\hline 3 & Difficulty in order processing & 6.145 \\
\hline 4 & Untimely delivery of products & 6.145 \\
\hline 5 & Mismatch between market demand and supplier responsiveness & 6.046 \\
\hline 6 & Inaccurate demand forecasting & 5.946 \\
\hline 7 & Problems communicating with your trading partners & 5.748 \\
\hline 8 & Break in information flow & 5.451 \\
\hline 9 & Costs of distant production & 5.055 \\
\hline 10 & Societal disruptions/strikes & 4.559 \\
\hline 11 & Risk of infringement of IPR & 4.559 \\
\hline 12 & Level of political instability & 4.460 \\
\hline 13 & Quality of skills, education level and talent of the labour force & 4.460 \\
\hline 14 & Difficulty in transmitting data & 4.361 \\
\hline 15 & Disparity in national cultures & 4.262 \\
\hline 16 & Mismatched inventory levels & 4.262 \\
\hline 17 & Accessibility of logistics provision & 4.163 \\
\hline 18 & Natural disasters and & 3.063 \\
\hline 19 & Quality of skills, education level and talent of the labour force & $\mathbf{1 0 0}$ \\
\hline 20 & Reliability of energy (power), internal trans & \\
\hline & telecommunication infrastructure & 3.964 \\
\hline & Total Percentage & \\
\hline & & \\
\hline
\end{tabular}

Table 3: Weight of Disturbance Factors

All interviewees from Phase III agreed that quality defects were the most important disturbance factor. According to the Sourcing Director of BP1, patient safety is the single most important factor. He explained that between 10-20 chemical transformations must occur to 
convert the raw material to the active ingredient. BP1 has a rigorous audit system to inspect supplier quality, including environmental health and safety audits.

The overall weight of each supply chain configuration (Figure 5) shows that the supply chain disturbance in Asia has the highest value (39.94\%), followed by Eastern Europe (32.90\%) and Western Europe (27.16\%). Firms generally enter markets they understand and where perceived uncertainty is low, and it is expected that supply chain disturbances will be lower in regions with less possibility of political unrest or natural disasters. This tendency is reflected in these results, which show environmental disturbances faced by the focal pharmaceutical firm with a manufacturing base in Western Europe have the lowest weight (10.8\%), whereas in Eastern Europe it is $14.5 \%$ and in Asia 18.1\%. Moreover, in Western Europe, the endogenous and exogenous disturbance factors are on average lower when compared to both Eastern Europe and Asia, which is most likely due to the advantages of less distant (less complex) supply chain configurations and better process control.

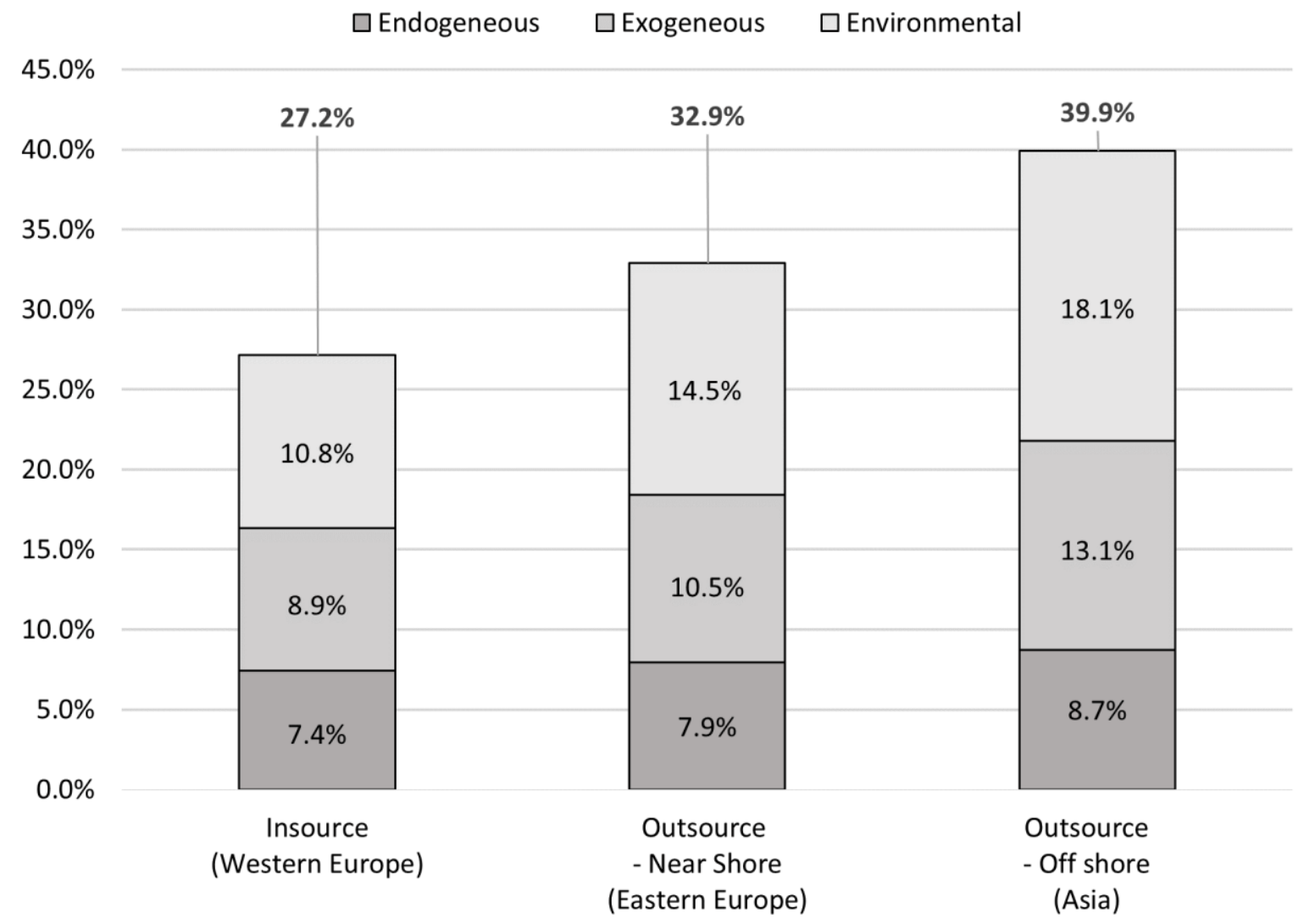

Figure 5: Overall Percentage Weights of Disturbance for alternative SC Configurations 
The weights of each of the 20 disturbance factors are displayed in Figure 6. Owing to space limitations, 10 factors have been highlighted for discussion (three endogenous, three exogenous and four environmental) in the following sections.

\section{Insource (Western Europe)}

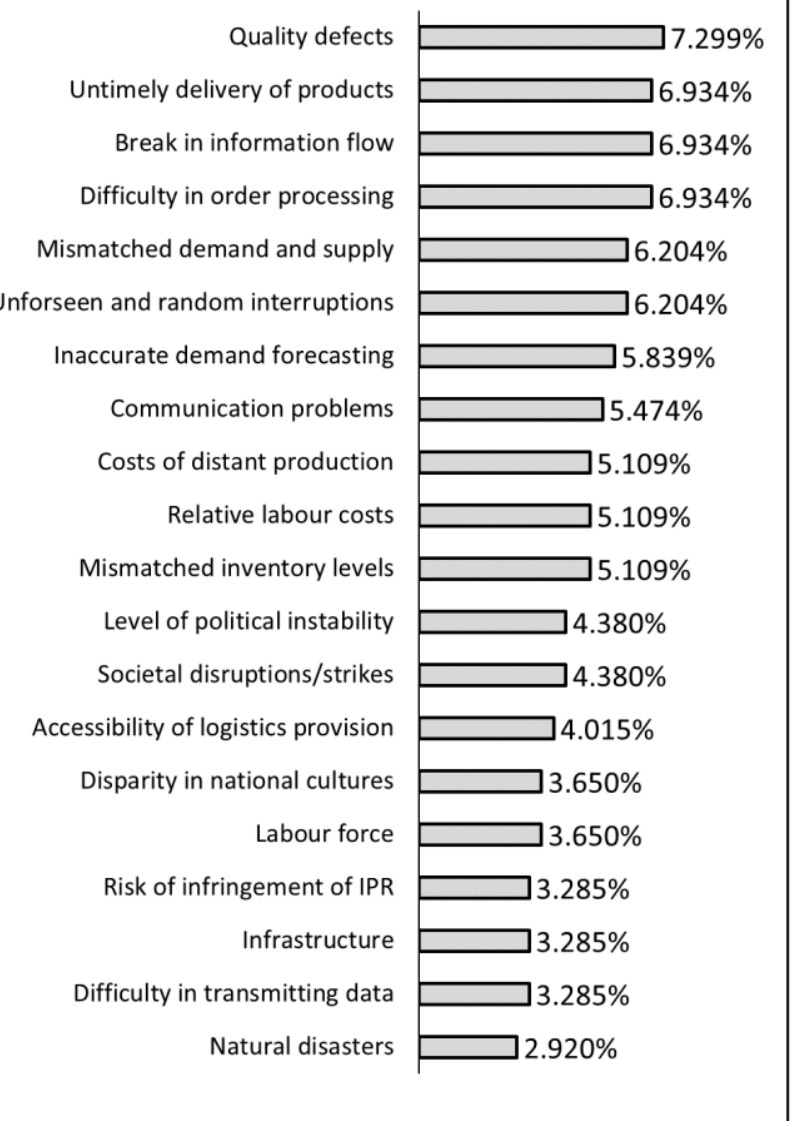

\section{Outsource Near Shore (Eastern Europe)}

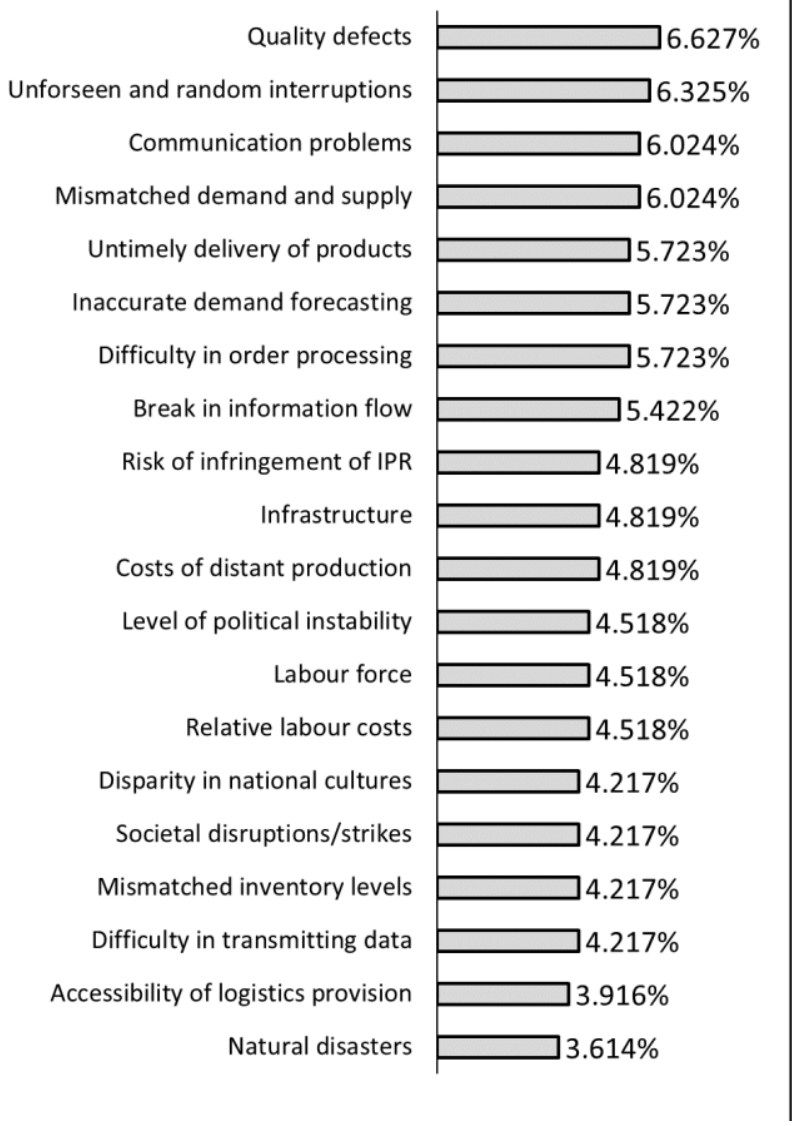

\section{Outsource Off Shore (Asia)}

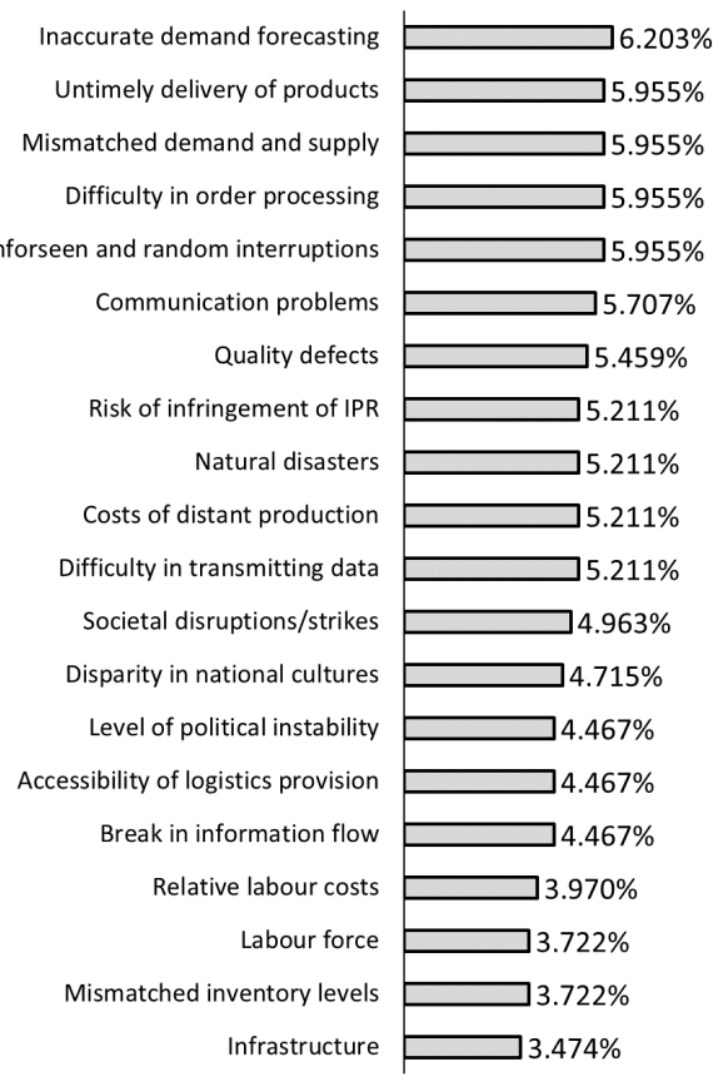

Figure 6: Ranking of Relative Weights of Disturbance Factors within the three Alternative SC Configurations 


\subsubsection{Endogenous disturbances}

- Quality defects were the top disturbance factor for Western and Eastern Europe. One of the interviewees pointed out they avoid suppliers who flout the rules and don't operate safely: “From our perspective, quality is king, geographical area doesn't matter. Quality is the major concern." In fact as per the view of the Senior SCM Director of BP1, cost takes a firm second place to quality. For example, Chinese suppliers are required to possess minimum levels of technical and compliance capability. Cost savings are present but relatively modest: they are on average only 30-40\% cheaper to their Western European counterparts. Cheaper Chinese suppliers are available but are not worth the risk.

- Unforeseen and random interruptions are important for all three locations. In Eastern Europe the risk is energy supply interruptions. For example, the 2009 Russia-Ukraine gas dispute led to Russia halting gas flow through Ukraine, completely cutting off supplies to South Eastern Europe for 13 days, much of which was completely reliant on Russian gas. On the other hand, power breakdowns in Asia are common, making backup generators a basic must have for an organisation's operating strategy. In Asia there are increased chances of other random unexpected interruptions occurring, e.g. labour strikes or taking holidays at short notice to attend weddings. In line with this, a Senior Supply Chain Director commented: "Overall we see more unplanned disturbance from Asia generally." These can cause big disruptions and disturbances in the entire supply chain with the cumulative effects being significant.

- Difficulty in order processing is also highly ranked. When sourcing from or manufacturing in distant regions, problems due to non-standardised systems (e.g. units of measurement), misunderstandings, disparity of cultures and traditions (e.g. language, religion, festivals, etc.) can occur. Reasons differ but can lie within the processes themselves, technical systems and/or communication issues. Translating orders from one language to another can cause miscommunication, as can non-standardised procedures for order processing, e.g. using commas instead of dots when entering numbers in a spreadsheet. Furthermore, incompatibilities of technical standards, procedures and processes remain an issue.

\section{$\underline{\text { 5.1.2 Exogenous disturbances }}$}

- Communication problems rank $4^{\text {th }}$ (relatively high) within Western Europe. This is counterintuitive as one would expect lower levels of miscommunication when suppliers/manufacturing units are closer to home. Communication is always a factor in supply chain management, and the lack of it will always contribute to increased exposure to disturbance.

- Inaccurate demand forecasting: The longer the supply chain, the greater the demand forecasting difficulties due to unreliable data, coupled with a lack of historical trends 
and projections. The Sourcing Director of BP1 agreed, especially when a new drug compound is under development: "If you have overestimated on how much you want, it is easy to turn it off and use that facility for something else. It is less easy if you underestimate... if the capacity is not there you cannot just magically find it elsewhere." The degree of unpredictability is especially high in Asia with confidence levels low, a point confirmed by a Senior Manager of BP: "Demand forecasting is currently much better in Western markets when compared to Asian regions."

- Difficulty in transmitting data was rated very low in Western Europe (19) and Eastern Europe (18), while in Asia it was mid-ranking (11). A case in point arose with BP1, whereby the Sourcing Director explained the situation with a (terminated) Indian supplier: "The supplier was pumping effluents into the river. These should have been treated as there was a potential risk of heavy metal contamination, as well as active pharmaceutical ingredients. The analysis of the effluent was monitored by a third party and rather than reporting the high metal level, they were diluting the samples and then analysing so that they all passed. When the government agency re-analysed the samples, they found that the effluent levels were ten times higher! The third-party auditor admitted the dilution practice... whereby they effectively falsified batch records and were lying about the products being made... Basically significant risks still exist in India regarding data integrity. This is known to the FDA who have raised concerns about classification of data at Indian companies."

\subsubsection{Environmental disturbances}

- National cultural differences: Although the Supply Chain Director from BP1 agreed with most of the weights, he would "rank cultural differences higher in Asia", emphasising that despite globalisation, cultural differences remain a challenge for managers dealing with distant suppliers. He considered that Western partners are "able to understand their business better". Regarding relations with Indian suppliers "It is not only about the capability, it is also about the leadership. It depends on the support you get from senior management..." Interestingly, when we interviewed BP1's executives during Phase II (2011-12), they were developing India as an outsourcing hub, but by Phase III (2015) they were scaling down their operations in India and shifting orders to China. The difference in attitude between BP1's Indian and Chinese suppliers was further demonstrated by its Sourcing Director: “...India has a very innovative culture...but suppliers spend a lot of time and effort working around the rules rather than within them. Chinese suppliers are very compliant - one can almost guarantee that they will follow the standard operating procedures." Interestingly, he noted that the Chinese government's role in enforcing regulation played a large part in standards compliance. According to him, the Melamine Scandal of 2008 whereby milk products were poisoned with melamine, leading to infant deaths and widespread sickness was a turning point for Chinese manufacturers - “7-8 years ago we wouldn't outsource any of the final stages or indeed anything that comes into contact with the patient....the melamine scandal was a wakeup call. We have seen over time that Chinese standards 
have vastly increased. When I look at the standard of their factories (now), they are where Western Europe was 12-15 years ago. They are catching up very quickly."

- Hidden costs of distant production: The Sourcing Director agreed that cost is a key driver in terms of where to outsource for long-term competitiveness. Even though costattractive suppliers are considered, the cheapest price is not always the best due to hidden costs associated with distant production. For example, dealing with complex chemistry requires close support from the BP. Travel from Europe to Asia to troubleshoot problems is time consuming and costly. Furthermore "if a problem occurs in Western Europe, I can guarantee to get someone there within two days, it can take twice as long to Asia". Some pharmaceutical products have a short shelf life requiring constant temperature control, especially if the product is an injectable liquid, e.g. insulin, for which a temperature of 2-8 degree Celsius must be maintained. To ensure a stable state when outside temperatures reach 30-35 degree Celsius is a major challenge, especially when shipping drugs across the Indian Ocean. Incorporating the required temperature controls incurs cost into the BP's logistics operations. Even regional differences in temperature within countries are not to be underestimated. For instance, winter temperatures in Northern China can dip to minus 30 degrees Celsius while in Southern China it is 20 degrees Celsius. Without careful planning, this variation provides scope for supply chain disruption.

- Societal disruptions arising man-made disasters, can potentially lead to disturbances. The deadly explosions in the port of Tianjin, China in August 2015, which also devastated large areas of the city, are a case in point. The initial blast took place at a port warehouse containing hazardous and flammable chemicals (BBC, 2015). This explosion impacted one of BP1's Chinese suppliers, whose plant was situated just 800 metres from the main explosion. BP1s Sourcing Director elaborated on the gravity of such disruptions: "(Since the blast) the supplier is not allowed to produce and the government is unhappy with the safety standards in the city, meaning we can't get material from that supplier which has a knock-on effect on our supply chain".

- Intellectual Property Rights (IPR) infringement risk: Looking across the three different configurations, there is little overlap in terms of the ranking of the key disturbance factors - except for IPR issues between Asia and Eastern Europe. According to the BP1 Sourcing Director, disturbances from the risk of IPR infringement is "very high in their list". The risk of drugs being counterfeit is also present, especially in China. There has been a proliferation of such activities and some high-profile cases e.g. counterfeit version of the cancer drug Avastin entering the US medical supply chain via online drug sales. These (cheaper) counterfeit drugs are re-packaged and sold in Western markets through Internet sites. BP1 is installing product security features (e.g. RFID tags and packaging holograms) in response. BP1 has also lobbied the Chinese government to bring penalties for selling counterfeit drugs in line with those for recreational drugs, which are currently much stricter. China is "showing promise in terms of rebranding of IPR compared to five years ago" (BP1). 


\subsection{Mitigation strategies}

Our findings indicate firms tackle supply chain disturbances by implementing the appropriate configuration. The right configuration will assist with enhancing supply chain performance, conversely a wrong choice will hinder performance. The objective should be to (re)design the supply chain for optimal performance, in line with supply chain objectives, while reducing the potential for disturbances. As this longitudinal study developed over a five year period, we had a unique opportunity to observe how disturbances were mitigated through recalibration of BP1's supply chain configurations. Indeed, three important recalibrations emerged:

\subsubsection{Reshoring/nearshoring core products:}

The first trend to emerge was reshoring/nearshoring of products, more specifically the insourcing of core products. In 2010, when we initiated this project, BPs were focused on outsourcing manufacture of both core and non-core drugs to cheaper locations with similar skill sets. BP1s Sourcing Director reminisced: "In 2007 we decided we wouldn't manufacture much of the material ourselves. So we closed down most of our facilities and knew we could buy the raw materials much cheaper externally." This situation changed drastically within 5 years as described by the Global Outsourcing Manager: "By 2010 there was a different approach to supply chain configuration. We are now focussing on core products (patented, high revenue drugs) and non-core products (generic). For out-patented non-core products we are looking at Asia and Eastern Europe - sourcing where labour is cheaper. Core products are usually sourced or manufacture from our core hubs (in Western Europe). This was not my answer five years ago, now we have multiple strategies." From its outsourcing experience of the past 10 years, BP1 realised it needed to have better control over its core products, as well as potential blockbuster drugs in the pipeline. Getting the product into the market at the right time is very important for core products because profit margins are very high.

BP1s Sourcing Director admitted that disturbance factors also influenced their decision to bring production back home (reshoring) or to a closer geography (nearshoring). This was due to both external (e.g. the Tianjin explosion) and internal events (e.g. the Indian supplier falsifying environmental data). After thorough investigations BP1 judged that poor data integrity (data transmission problems) from Indian suppliers was too high and thus ceased carrying out core functions in India. The Sourcing Director predicted additional significant investments in developing BP1's internal drug manufacturing capability.

\subsubsection{Outsourcing offshore non-core products:}

For non-core drugs BP1 sought solutions to reduce supply chain costs. The new strategy for BP1 was to use the cheaper Asian suppliers for non-core low tech, 'simpler' products, while sourcing core products from Western Europe for increased control and maximum quality assurance. BP1 decided not to keep non-core activities in house, especially those that involved simple chemistry, as it believed the quality of Asian suppliers would be acceptable, but the price comparatively lower. According to the Senior Director of SCM, India as an outsourcing location was not as attractive as China mainly due to lack of compliance and poor performance 
of suppliers. In fact, during Phase III (2013-15) many orders had shifted to China from India. To reduce exogenous control disturbances, BP1 introduced robust audit processes to validate suppliers' compliance with its ethical, safety, environmental and quality requirements. BP1 was also following a multi-sourcing strategy while outsourcing offshore. As indicated by the Sourcing Director, policy is that two primary suppliers deliver two-thirds of its required capacity. Thus it was evident that BP1 was taking a more cautious, risk-averse approach to outsource offshoring and sought to ensure that it has a large enough supplier base for it noncore products in the event of supply chain disturbances.

\section{$\underline{5.2 .3 \text { Insourcing offshore }}$}

In Phase III (2013-15), an interesting and unexpected phenomena started to occur - BP1 began insourcing offshore. BP1 was in the process of setting up what it called 'captives' both in Eastern Europe and Asia. These captives serve as an outreach independent businesses for BP1, with their individual bottom-line accountability and budget. The Global Outsourcing Manager explained the logic behind such a radical recalibration of the supply chain: "We used to outsource a lot of our products but due to lack of trust in suppliers.... in the last two years things have changed, especially in procurement, supply chain and operations. The business models are evolving... This is a learning curve, a cycle - four years ago we were outsourcing everything to Asia, but now we are starting to use captives...In the longer term we would like to see standardisation, so want to keep similar suppliers."

One of the underlying objectives of having captives is to reduce the focal firm's reliance on external partners. BP1 has offshore operations of its own, as well as offshore partners. By using such a hybrid model, BP1 aims to build the capabilities of its captives by absorbing the knowledge from its best outsourcing partners. Within two years BP1 expects its captives to develop their own capabilities. It then plans to slowly exit its external suppliers and focus business on the captives. This kind of insourcing offshore has a number of advantages. Namely, these captives help alleviate some of the control and cultural disturbances and more importantly mitigate IPR infringement risks that they are exposed to with external suppliers. The captives are thus in essence an extension of the focal firm. According to the Global Outsourcing Manager, BP1 will be able to simplify, standardise and optimise its processes across the globe by developing such captives. This kind of supply chain configuration resembles a hub-andspoke model, where the Eastern European or Asian spokes drive efficiencies and the central Western European hubs drive innovation (R\&D). 


\subsubsection{Supply chain disturbance framework}

Resulting from the literature review and our findings, we constructed the Supply Chain Disturbance Framework (Figure 7). Here we identify supply chain-wide disturbances of a Western European-based BP in relation to the three possible supply chain configurations. The framework is developed to account for disturbances (risk and uncertainty) caused by factors internal and external to the focal firm. The Supply Chain Disturbance Framework incorporates firm-, network- and site-related disturbance factors and their potential impact on different supply chain configurations. This requires reconfiguring the supply chain in order to keep pace with the changing environment. We assert that supply chain disturbance factors affect particular configurations in different ways, which in turn are mitigated through different reconfiguration strategies.

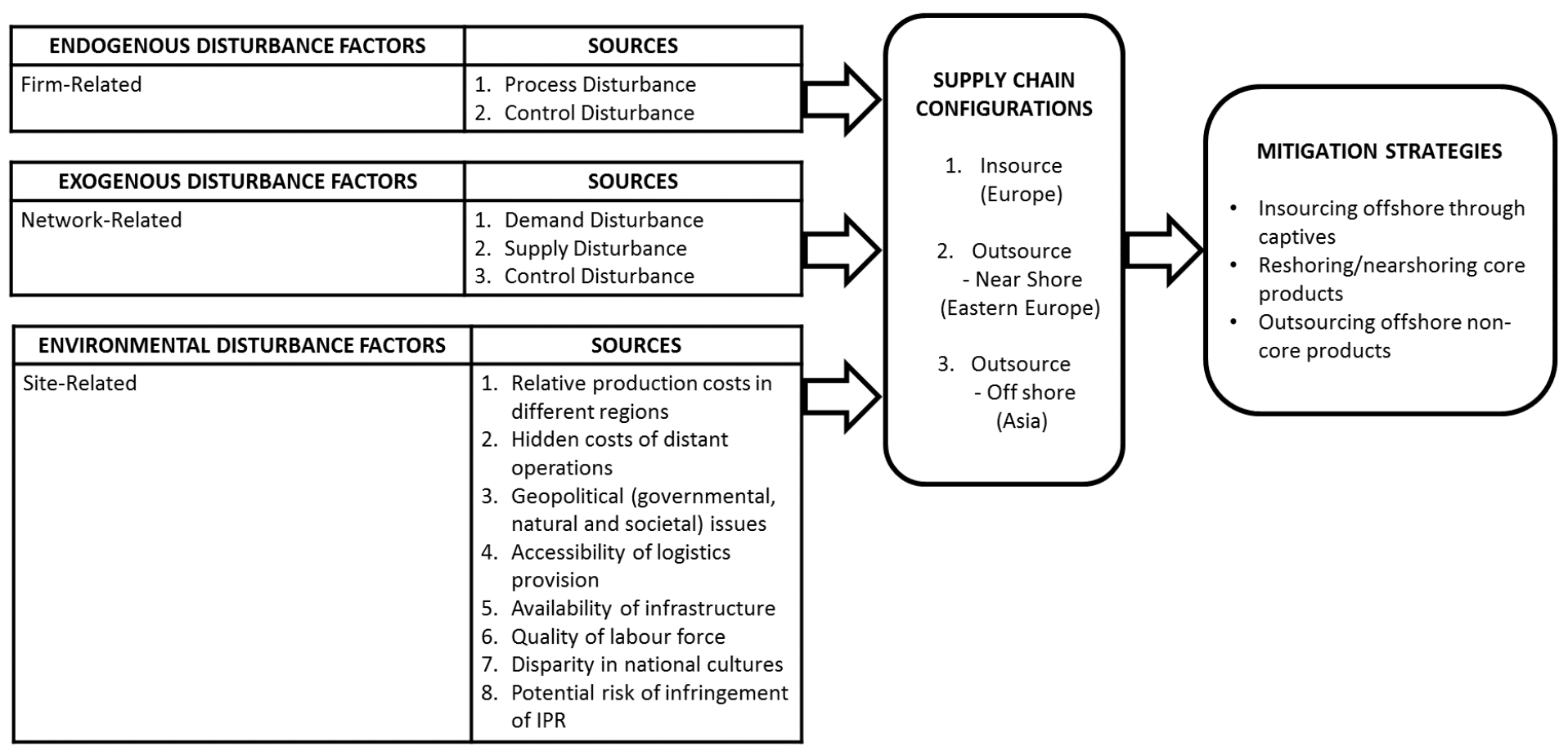

Figure 7: The Supply Chain Disturbance Framework 


\section{Conclusions}

In this paper, different supply chain configuration strategies for Western European pharmaceutical firms are explored and a framework is developed to assess the level of disturbance factors associated with, outsourcing to and/or locating manufacturing operations in, three major regions: Western Europe, Eastern Europe and Asia. Through a multi-phase, mixed-method approach carried out, over a period of five years, we find that the top five disturbance factors managers should be aware of while configuring their supply chains are quality defects, unforeseen and random interruptions in manufacturing processes, order processing difficulties, untimely delivery of products, and a mismatch between market demand and supplier responsiveness. Interestingly, a number of novel factors were also identified. For example, our results demonstrated that quality defects represent the top disturbance factor for Western and Eastern Europe. This shows that the cost of quality defects has implications all along the supply chain, especially given the critical nature of pharmaceutical products. The reason for ranking quality disturbances the highest in Western Europe perhaps reflects the stricter standards by both consumers and regulatory bodies as well as the potentially grave negative impacts on the business. A further counterintuitive finding was that communication problems were ranked quite high $\left(4^{\text {th }}\right)$ within Western Europe. This suggests that there can still be miscommunication and misunderstandings even when suppliers/manufacturing units are closer to home. Our data analysis also provides a nuanced view of how these disturbances differ in different countries within regions e.g. higher cultural disparity and greater difficulties in transmission of data in India caused BP1 to shift their orders.

Most previous studies on supply chain design and disturbances have explored how supply chain design characteristics affect the degree of supply chain disruptions (Craighead et al., 2007). Even recently, Habermann et al. (2015) investigated supply chain disturbances in co-located and dispersed supply chain designs and found that co-location with suppliers is related to shorter duration of disruptions. However, the study of the effect of disturbances on supply chain design, and supply chain re-configuration as a disturbance mitigating strategy is relatively unexplored. Our findings show that in this era of increased potential disturbances, it is not enough to just consider between alternative design strategies, rather firms need to be flexible and adaptable (Christopher and Holweg, 2011). Interestingly, we found empirical evidence of supply chain disturbances influencing firms to bring production back home (reshoring) or to a closer location (near-shoring). The underlying reasons for reconfiguring supply chain strategies included both exogenous disturbance factors (e.g. the Tianjin explosion in China, which had detrimental effect on SC performance) and endogenous disturbance factors (e.g. lack of data integrity - a supplier falsifying environmental data).

\subsection{Managerial implications}

This research offers useful insights for managers by providing a detailed conceptual framework of the supply chain disturbance constructs. Furthermore, the study highlights how important it is for the focal pharmaceutical firms to understand that disturbances can occur at all levels within the supply network. By being aware of the key disturbance factors in different supply chain configurations, managers will be better equipped to predict the challenges they are likely 
to face, allowing them to either avoid or overcome them. For example, to mitigate the effects of disturbances, firms can recalibrate their supply chain configurations by insourcing core products, outsourcing non-core products offshore and developing offshore insourcing capabilities through 'captives'. These findings can be generalised to an extent to other similar industries, for instance the food industry where certain disturbances affecting the supply chain can also potentially threaten consumers' lives e.g. the 2008 contamination of milk products with melamine in China, which sickened thousands and led to the death of six babies. Therefore, repercussions of such critical consequences is forcing managers to rethink their supply chain configuration and this study will help them deploy appropriate strategies to mitigate disturbances.

\subsection{Limitations and Future Research}

Although this study is based on insights from the pharmaceutical industry, non-industry specific elements (e.g. majority of the disturbance factors) can be applied and extended to other sectors. However, it should be taken into account that there is no 'one-size-fits-all' strategy, and even in firms in similar sectors supply chain design differs, owing to unique characteristics. Therefore, it is important to note that some of the supply chain configurations presented in this paper would not be appropriate for particular drug types and that the locations suggested might in certain cases not be feasible due to regulatory issues. Thus, other measures may be relevant and should be considered by firms and supply chain participants to reflect their unique needs.

Through this longitudinal multi-phase, mixed methods study, the dynamic nature of the pharmaceutical industry has been highlighted. Our findings show how supply chain disturbances lead to a change in strategies at the macro level (reconfigurations). However, the effect of disturbances at the micro level, in particular on supply chain performance metrics has not been addressed. Therefore, there remains a need for additional empirical research on how disturbance factors impact the performance of the supply chain configurations (e.g. in terms of lead time, inventory, quality, flexibility, customer responsiveness and cost). This research provides a base for systems modellers, who, if given access to appropriate data, can begin the task of developing more complete predictive simulations of the likely effects of disturbances on the performance of different supply chain configurations. It would also be interesting to examine how supply chain reconfiguration compares with other risk mitigation strategies (e.g. product management, process improvements, supply chain integration, capital adequacy etc.). Once developed, these models could provide assistance for managers and policy makers. Further research could also focus on conducting in-depth multi-tier case studies in additional industry sectors and evaluate the importance of each disturbance factor with respect to different supply chain configurations through Analytic Hierarchy Process or Analytic Network Process methods.

Acknowledgement:

This research was collaboratively funded by EPSRC, RCUK [EP/G039933/1]; DST, India. Title: RCUK-DST India Science Bridge BioPharm 2020: Entrepreneurial Opportunities for Indian/UK Scientists in Pharmaceutical and Biotechnology Industries. 


\section{References}

Astrazeneca, (2010), "Annual Report", available at: http://www.astrazeneca.com/Investors/Annual-reports, Accessed 16 August, 2011.

ATKearney, (2005), "Making offshore Decisions. A.T. Kearney’s 2004 Offshore Location Atractiveness Index", Available available at: <http://www.atkearney.com/index.php/Publications/making-offshore-decisions.html>, Accessed on 28th of August, 2011.

Bazeley, P. (2008), Mixed methods in management research, in Thorpe, R. \& Holt, R. (Ed.), The SAGE Dictionary of Qualitative Management Research. London: Sage. pp. 133136

BBC, (2015), "China explosions: What we know about what happened in Tianjin", available at: http://www.bbc.co.uk/news/world-asia-china-33844084, Accessed on 20th November, 2015.

Bhatnagar, R. and Sohal, A. S. (2005), "Supply chain competitiveness: measuring the impact of location factors, uncertainty and manufacturing practices", Technovation, Vol. 25 No. 5, pp. 443-456.

Blackhurst, J., Wu, T. and O'grady, P. (2007), "A network-based decision tool to model uncertainty in supply chain operations", Production Planning and Control, Vol. 18 No. 6, pp. 526-535.

Bloomberg, (2008), "China and U.S. Clash Over Cause of Heparin Deaths", available at: http://www.bloomberg.com/apps/news\%3Fpid=newsarchive\%26sid=aUAE9VN4.xX 0\%26refer=home\%23, Accessed on 30 Nov, 2014.

Bode, C., Wagner, S. M., Petersen, K. J. and Ellram, L. M. (2011), "Understanding responses to supply chain disruptions: insights from information processing and resource dependence perspectives", Academy of Management Journal, Vol. 54 No. 4, pp. 833856.

Carter, J. R. and Narasimhan, R. (1996), "Purchasing and supply management: future directions and trends", Journal of supply chain management, Vol. 32 No. 4, pp. 2-12.

Chan, F. T. S., Kumar, N., Tiwari, M. K., Lau, H. C. W. and Choy, K. L. (2008), "Global supplier selection: a fuzzy-AHP approach", International Journal of Production Research, Vol. 46 No. 14, pp. 3825-3857.

Chopra, S. and Sodhi, M. M. S. (2004), "Managing risk to avoid supply-chain breakdown", MIT Sloan Management Review, Vol. 46 No. 1, pp. 53-61.

Christopher, M. and Holweg, M. (2011), "Supply Chain 2.0": managing supply chains in the era of turbulence", International Journal of Physical Distribution \& Logistics Management, Vol. 41 No. 1, pp. 63-82.

Christopher, M. and Lee, H. (2004), "Mitigating supply chain risk through improved confidence", International Journal of Physical Distribution \& Logistics Management, Vol. 34 No. 5, pp. 388-396.

Christopher, M. and Peck, H. (2004), "Building the resilient supply chain", International Journal of Logistics Management, The, Vol. 15 No. 2, pp. 1-14.

Cockburn, R., Newton, P. N., Agyarko, E. K., Akunyili, D. and White, N. J. (2007), "The global threat of counterfeit drugs: why industry and governments must communicate the dangers", PLoS Medicine, Vol. 2 No. 4, pp. e100.

Craighead, C. W., Blackhurst, J., Rungtusanatham, M. J. and Handfield, R. B. (2007), "The severity of supply chain disruptions: design characteristics and mitigation capabilities", Decision Sciences, Vol. 38 No. 1, pp. 131-156.

Davis, T. (1993), "Effective supply chain management", Sloan Management Review, Vol. 34 No. Summer 1993, pp. 35-46. 
Division, U. N. S., (2013), "Composition of macro geographical (continental) regions, geographical sub-regions, and selected economic and other groupings", available at: http://unstats.un.org/unsd/methods/m49/m49regin.htm, Accessed 18th September, 2013.

Ellis, S. C., Shockley, J. and Henry, R. M. (2011), "Making Sense Of Supply Disruption Risk Research: A Conceptual Framework Grounded In Enactment Theory", Journal of Supply Chain Management, , Vol. 47 No. 2, pp. 65-96.

Ellram, L. M., Tate, W. L. and Petersen, K. J. (2013), "Offshoring and Reshoring: An Update on the Manufacturing Location Decision", Journal of Supply Chain Management, Vol. 49 No. 2, pp. 14-22.

Enyinda, I. C., Briggs, C. and Bachkar, K. (2009), "Managing risk in pharmaceutical global supply chain outsourcing: Applying analytic hierarchy process model", American Society of Business and Behavioral Sciences. Las Vegas (vol. 16).

Erber, G. and Sayed-Ahmed, A. (2005), "Offshore outsourcing. A global shift in the present", IT Industry, Intereconomics, Vol. 40 No. 2, pp. 100-12.

Evans, G., Naim, M. M. and Towill, D. R. (1993), "Dynamic supply chain performance: Assessing the impact of information systems", Logistics Information Management, Vol. 6 No. 4, pp. 15-25.

FDA, (2008), "FDA's Ongoing Heparin Investigation", available at: http://www.fda.gov/NewsEvents/Testimony/ucm115242.htm, Accessed on 30 Dec, 2014.

Fiercepharma, (2013), "Top Pharma Companies by 2012 Revenues", available at: http://www.fiercepharma.com/special-reports/top-pharma-companies-2012-revenues, 31 st Jan, 2014.

Fisher, M. L. (1997), "What is the right supply chain for your product?", Harvard Business Review, Vol. 75 No. March, pp. 105-117.

Geary, S. (2002), "Uncertainty and the seamless supply chain", Supply Chain Management Review, Vol. 6 No. 4, pp. 52-61.

Habermann, M., Blackhurst, J. and Metcalf, A. Y. (2015), "Keep Your Friends Close? Supply Chain Design and Disruption Risk", Decision Sciences, Vol. 46 No. 3, pp. 491-526.

Harland, C., Brenchley, R. and Walker, H. (2003), "Risk in supply networks", Journal of Purchasing and Supply Management, Vol. 9 No. 2, pp. 51-62.

Harvey, W. S. (2011), "Strategies for conducting elite interviews", Qualitative Research, Vol. 11 No. 4, pp. 431-441.

Hendricks, K. B. and Singhal, V. R. (2005), "An Empirical Analysis of the Effect of Supply Chain Disruptions on Long Run Stock Price Performance and Equity Risk of the Firm", Production and Operations Management, Vol. 14 No. 1, pp. 35-52.

Hendricks, K. B., Singhal, V. R. and Zhang, R. (2009), "The effect of operational slack, diversification, and vertical relatedness on the stock market reaction to supply chain disruptions", Journal of operations management, Vol. 27 No. 3, pp. 233-246.

Jüttner, U. (2005), "Supply chain risk management: understanding the business requirements from a practitioner perspective", International Journal of Logistics Management, Vol. 16 No. 1, pp. 120-141.

Jüttner, U., Peck, H. and Christopher, M. (2003), "Supply chain risk management: outlining an agenda for future research", International Journal of Logistics : Research \& Applications, Vol. 6 No. 4, pp. 197-210.

Knemeyer, A. M., Zinn, W. and Eroglu, C. (2009), "Proactive planning for catastrophic events in supply chains", Journal of operations management, Vol. 27 No. 2, pp. 141-153.

KPMG, (2011), "China's Pharmaceutical Industry - Poised for the giant leap", available at: http://www.kpmg.com/CH/en/Library/Articles- 
Publications/Documents/Sectors/pub_20110601_Chinas-Pharmaceuticals-andBiotechnology-Industries_EN.pdf, Accessed on 25 August, 2011.

Lalwani, C., Pawar, K. and Shah, J., (2007), "Contextualisation framework for the manufacturing supply chain." Centre for Concurrent Enterprise, the University of Nottingham.

Lee, H. L. (2002), "Aligning supply chain strategies with product uncertainties", California management review, Vol. 44 No. 3, pp. 105-119.

Lockamy, A., Childerhouse, P., Disney, S. M. and Towill, D. R. (2008), "The impact of process maturity and uncertainty on supply chain performance: an empirical study", International Journal of Manufacturing Technology and Management, Vol. 15 No. 1, pp. 12-27.

MacCarthy, B. L. and Atthirawong, W. (2003), "Factors affecting location decisions in international operations-a Delphi study", International Journal of Operations \& Production Management, Vol. 23 No. 7, pp. 794-818.

Marucheck, A., Greis, N., Mena, C. and Cai, L. (2011), "Product safety and security in the global supply chain: Issues, challenges and research opportunities", Journal of Operations Management, Vol. 29 No. 7-8, pp. 707-720.

Mason-Jones, R. and Towill, D. R. (1998), "Shrinking the supply chain uncertainty circle", IOM Control, Vol. 24 No. 7, pp. 17-22.

McKinsey, (2012), "Expect the unexpected: Reduce corporate exposure and create value through supply chain risk management", available at: http://www.mckinsey.com/client_service/mckinsey_capability_building/people/ /med $\mathrm{ia} /$ mckinsey/dotcom/client_service/operations/pdfs/expect_the_unexpected.ashx, Accessed on 29th Nov, 2014.

Miller, J. (2011), "Supply-Chain Pain", Pharmaceutical Technology, Vol. 35 No. 5, pp. 92-94.

Mizgier, K. J., Hora, M., Wagner, S. M. and Jüttner, M. P. (2015a), "Managing operational disruptions through capital adequacy and process improvement", European Journal of Operational Research, Vol. 245 No. 1, pp. 320-332.

Mizgier, K. J., Wagner, S. M. and Holyst, J. A. (2012), "Modeling defaults of companies in multi-stage supply chain networks", International Journal of Production Economics, Vol. 135 No. 1, pp. 14-23.

Mizgier, K. J., Wagner, S. M. and Jüttner, M. P. (2015b), "Disentangling diversification in supply chain networks", International Journal of Production Economics, Vol. 162 No. pp. 115-124.

New York Times, (2011), "Johnson \& Johnson's Profit Falls 12\%, Hurt by Series of Recalls", available at: http://www.nytimes.com/2011/01/26/business/26drug.html, Accessed on 29th Nov, 2014.

Onwuegbuzie, A. J. and Collins, K. M. (2007), "A typology of mixed methods sampling designs in social science research", The Qualitative Report, Vol. 12 No. 2, pp. 281-316.

Pawar, K. and Rogers, H. (2013), "Contextualising the holistic cost of uncertainty in outsourcing manufacturing supply chains", Production Planning \& Control: The Management of Operations, Vol. 24 No. 7, pp. 607-620.

Peck, H. (2005), "Drivers of supply chain vulnerability: an integrated framework", International Journal of Physical Distribution \& Logistics Management, Vol. 35 No. 4, pp. 210-232.

Pfizer, (2010), "Annual Report", available at: http://www.pfizer.com/investors/financial_reports/financial_reports.jsp, Accessed 16 August, 2011.

Porter, M. E. and Kramer, M. R. (2011), "The big idea: Creating shared value", Harvard Business Review, Vol. 89 No. 1-2, pp. 63-77. 
Prater, E. (2005), "A framework for understanding the interaction of uncertainty and information systems on supply chains", International Journal of Physical Distribution \& Logistics Management, Vol. 35 No. 7, pp. 524-539.

Prater, E., Biehl, M. and Smith, M. A. (2001), "International supply chain agility-Tradeoffs between flexibility and uncertainty", International Journal of Operations \& Production Management, Vol. 21 No. 5/6, pp. 823-839.

PWC, (2007), "Pharma 2020: The vision", available at: http://www.pwc.com/gx/en/pharmalife-sciences/pharma-2020, Accessed July 20, 2011.

Rogers, H., Pawar, K. and Braziotis, C. (2012), Supply Chain Disturbances: Contextualising the Cost of Risk and Uncertainty in Outsourcing, in Chan Hk, L. F. a. D. O. (Ed.), Decision-Making for Supply Chain Integration. London: Springer pp. 145-164.

Rogers, L. K., (2010), "Wood pallets cited as cause for McNeil's Tylenol recall", available at: http://www.supplychain247.com/article/wood_pallets_cited_as_cause_for_mcneils_ty lenol_recall/0, Accessed on 30 Nov. 2014.

Saunders, M., Lewis, P. and Thornhill, A. (2009), Research methods for business students. Harlow, UK: Pearson Education.

Sheffi, Y. and Rice, J. B. (2005), "A supply chain view of the resilient enterprise", MIT Sloan Management Review, Vol. 47 No. 1, pp. 41.

Simangunsong, E., Hendry, L. C. and Stevenson, M. (2012), "Supply-chain uncertainty: a review and theoretical foundation for future research", International Journal of Production Research, Vol. 50 No. 16, pp. 4493-4523.

Simchi-Levi, D. (2010), "Your Next Supply Chain", MIT Sloan Management Review, Vol. 51 No. 2, pp. 17-24.

Skibo, A. D., (2013), "Weighing Supply Chain Cost Versus Risk in Pharmaceutical Outsourcing", available at: http://www.pharmoutsourcing.com/FeaturedArticles/150934-Weighing-Supply-Chain-Cost-Versus-Risk-in-PharmaceuticalOutsourcing/, Accessed on 29 Nov, 2014.

Spekman, R. E. and Davis, E. W. (2004), "Risky business: expanding the discussion on risk and the extended enterprise", International Journal of Physical Distribution \& Logistics Management, Vol. 34 No. 5, pp. 414-433.

Srai, J. S. and Gregory, M. (2008), "A supply network configuration perspective on international supply chain development", International Journal of Operations \& Production Management, Vol. 28 No. 5, pp. 386-411.

Srinivasan, M., Mukherjee, D. and Gaur, A. S. (2011), "Buyer-supplier partnership quality and supply chain performance: Moderating role of risks, and environmental uncertainty", European Management Journal, Vol. 29 No. 4, pp. 260-271.

Tang, C. S. (2006), "Perspectives in supply chain risk management", International Journal of Production Economics, Vol. 103 No. 2, pp. 451-488.

Tang, O. and Musa, S. N. (2011), "Identifying risk issues and research advancements in supply chain risk management", International Journal of Production Economics, Vol. 133 No. 1, pp. 25-34.

Taps, S. B. and Steger-Jensen, K. (2007), "Aligning supply chain design with manufacturing strategies in developing regions", Production Planning \& Control, Vol. 18 No. 6, pp. 475-486.

The Chartered Quality Institute, (2012), "A guide to supply chain risk management for the pharmaceutical and medical devices industries and their suppliers", available at: http://www.thecqi.org/Community/Special-Interest-Groups-SIGs/PharmaceuticalQuality-Group/PQG-guide/, Accessed on 30th Nov, 2014. 
Van Der Vorst, J. G. a. J. and Beulens, A. J. M. (2002), "Identifying sources of uncertainty to generate supply chain redesign strategies", International Journal of Physical Distribution \& Logistics Management, Vol. 32 No. 6, pp. 409-430.

Wagner, S. M. and Neshat, N. (2012), "A comparison of supply chain vulnerability indices for different categories of firms", International Journal of Production Research, Vol. 50 No. 11, June, pp. 2877-2891.

Wagner, S. M., Mizgier, K. J. and Arnez, P. (2014), "Disruptions in tightly coupled supply chain networks: the case of the US offshore oil industry", Production Planning \& Control, Vol. 25 No. 6, pp. 494-508.

Wall Street Journal, (2007), "AstraZeneca Outsources to China, Re-Tools U.K. Distribution", available at: http://blogs.wsj.com/health/2007/10/22/astrazeneca-outsources-to-chinare-tools-uk-distribution/, Accessed on 29th Nov, 2014.

Wiengarten, F., Humphreys, P., Gimenez, C. and Mcivor, R. (2016), "Risk, risk management practices, and the success of supply chain integration", International Journal of Production Economics, Vol. 171, Part 3 No. pp. 361-370.

Wilding, R. (1998), "The supply chain complexity triangle: uncertainty generation in the supply chain", International Journal of Physical Distribution \& Logistics Management, Vol. 28 No. 8, pp. 599-616.

Wright, D. and Albores, P., (2010), "Resilience strategies to counteract supply chain risk: a simulation analysis." euroma2010.

Wu, T., Blackhurst, J. and O'grady, P. (2007), "Methodology for supply chain disruption analysis", International Journal of Production Research, Vol. 45 No. 7, pp. 1665-1682.

Zsidisin, G. A. (2003a), "A grounded definition of supply risk", Journal of Purchasing and Supply Management, Vol. 9 No. 5-6, pp. 217-224.

Zsidisin, G. A. (2003b), "Managerial perceptions of supply risk", Journal of supply chain management, Vol. 39 No. 1, pp. 14-26.

Zsidisin, G. A., Melnyk, S. A. and Ragatz, G. L. (2005), "An institutional theory perspective of business continuity planning for purchasing and supply management", International Journal of Production Research, Vol. 43 No. 16, pp. 3401-3420. 